\title{
Novel Lipid Constituents Identified in Seeds of Nigella sativa (Linn)
}

\author{
B. K. Mehta,* Manjul Verma and Meenal Gupta \\ School of Studies in Chemistry and Biochemistry, Vikram University, Ujjain 456010, M.P., India
}

\begin{abstract}
Lipídeos inéditos foram isolados de matéria insaponificável extraída de sementes de Nigella sativa Linn, usando-se n-hexano. O dienoato e os dois monoésteres inéditos foram identificados por técnicas espectrométricas, incluindo IV, RMN de ${ }^{1} \mathrm{He}^{13} \mathrm{C}$, espectrometria de massas, e análise química. O dienoato (1) foi identificado como metilnonadeca-15, 17-dienoato e os dois monoésteres foram identificados como pentil hexadec-12-enoato (2) e pentil pentadec-11-enoato (3). Ácido linoleico, ácido oléico, $\beta$-sitosterol e stigmasterol foram identificados como parte das estruturas dos lipídeos. Todos os compostos mostraram atividade moderada contra Staphylococcus aureus e baixa atividade contra shigella spp e Klebsiella pneumoniae.
\end{abstract}

Novel lipids were isolated from the unsaponifiable matter extracted from seeds of Nigella sativa Linn by using $n$-hexane. The new dienoate and two monoesters were the new lipids identified by spectral (IR, ${ }^{1} \mathrm{H}$ - and ${ }^{13} \mathrm{C}$-NMR spectra, mass spectrum, elemental analysis) and chemical analysis. The dienoate (1) was identified as methylnonadeca-15,17-dienoate and two monoesters were identified as pentyl hexadec-12-enoate (2) and pentyl pentadec-11-enoate (3). Linoleic acid, oleic acid, $\beta$-sitosterol and stigmasterol were identified as part of the lipid structures. All compounds exhibited moderate activity against Staphylococcus aureus and poor activity against shigella spp, and Klebsiella pneumoniae.

Keywords: Nigella sativa, seeds, Ranunculaceae, aliphatic esters

\section{Introduction}

Nigella sativa Linn., a plant belonging to the family Ranunculaceae, grows as a small herb and is cultivated throughout India and other tropical regions of the world. ${ }^{1,2}$ It is commonly known as black cumin seed and kalaungi in Hindi in India. The seed contains alkaloids nigellidine, ${ }^{3}$ nigellimine and nigellicine,${ }^{4,5}$ tannin, steroids $\alpha$-spinasterol, ${ }^{6}$ campesterol, cholesterol, stigmasta-7-en$3 \beta$-ol, stigmasterol and $\beta$-sitosterol, flavonoids of trigillin quercetin-3-glucoside, saponin and nigellone. ${ }^{7,8}$ Recent pharmacological investigations of the seed extract revealed that a wide spectrum of biological activities including anti-inflammatory, antidiabetic, analgesic, antibacterial, antifungal, anti-helmintic, ${ }^{9}$ bronchodilatory, ${ }^{10}$ hypertensive and immunoprotecting activities. ${ }^{11}$ The seeds are believed to have carminative, diuretic, lactogoge, stimulatory and diaphoretic properties and are used in the treatment of bronchial asthma and eczema. ${ }^{12-15}$ The hexane and benzene extracts of its seeds were exhibited $67 \%$ and $40 \%$

\footnotetext{
*e-mail: bkmehta11@yahoo.com
}

post-coital anti-implantation activity at the dose level of $500 \mathrm{mg} \mathrm{kg}^{-1}$ per day, respectively. ${ }^{16}$

The present study reports the isolation and structural elucidation of three new lipids (Figure 1) isolated from seeds of Nigella sativa Linn. Linoleic acid, oleic acid, $\beta$-sitosterol and stigmasterol were identified as part of the structures of the new lipids.

\section{Results and Discussion}

The novel natural compounds were identified mainly by their $1 \mathrm{D}\left({ }^{1} \mathrm{H}\right.$ and $\left.{ }^{13} \mathrm{C} \mathrm{NMR}\right), 2 \mathrm{D}\left({ }^{1} \mathrm{H}-{ }^{1} \mathrm{H}\right.$ COSY $)$, DEPT and mass spectrometry analysis, including comparison with literature data.

The mass spectrum and elemental analysis of methyl nonadeca-15,17-dienoate (1) indicated the molecular ion peak at $m / z, 308$ suggesting its molecular formula $\mathrm{C}_{20} \mathrm{H}_{36} \mathrm{O}_{2}$. IR spectrum showed absorption bands for ester group (1730 $\mathrm{cm}^{-1}$ ), for unsaturation $\left(1651,1627 \mathrm{~cm}^{-1)}\right.$ and long chain aliphatic nature $\left(1020,730-720 \mathrm{~cm}^{-1}\right) \cdot{ }^{17,18}{ }^{1} \mathrm{H}$ NMR spectrum showed a doublet at $\delta 1.60$ for three protons was due to terminal methyl groups present at vinylic position, while a singlet at $\delta 3.64$ for three protons was due to other terminal 


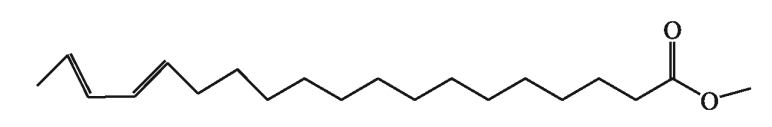

1

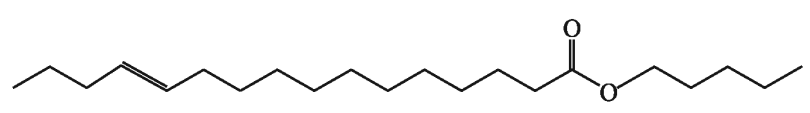

2

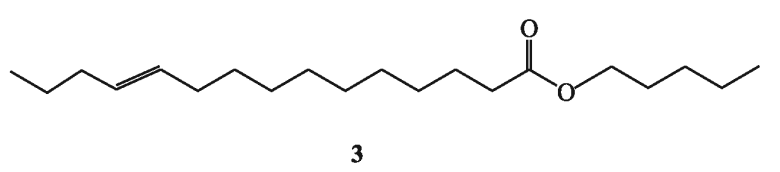

Figure 1. Chemical structures of 1-3.

carbomethoxyl $\left(-\mathrm{COOCH}_{3}\right) \cdot{ }^{19}$ The methylene protons adjacent to carbomethoxyl (- $\left.\mathrm{CH}_{2}-\mathrm{COO}-\right)$ moiety were resonated as triplet at $\delta 2.36$. A multiplet at $\delta 1.56$ was due to the presence of methylene protons $\beta$ - to double bond and ester group. A multiplet at $\delta 5.35(4 \mathrm{H}, J 5.4 \mathrm{~Hz})$ was due to the unsaturated protons which are in cis configuration, confirmed by absorption band at $730 \mathrm{~cm}^{-1}$ in IR spectrum. ${ }^{17}$ Rests of the methylenes were resonated at $\delta 1.25$ as an intense singlet.

The ${ }^{13} \mathrm{C}$ NMR spectrum showed the presence of terminal methyl carbon at $19.9 \mathrm{ppm}$. The carbon of ester group was resonated at $174.0 \mathrm{ppm}$. The olefinic carbons at C-15 and $\mathrm{C}-18$ were resonated at $118.0 \mathrm{ppm}$ while $\mathrm{C}-16$ and $\mathrm{C}-17$ were resonated at $122.0 \mathrm{ppm}$ which revealed presence of conjugated double bond. The methylene carbons, $\alpha$ - and $\beta$ - to ester group were resonated at 34.5 and $32.0 \mathrm{ppm}$ respectively and rest of the methylene carbons were resonated at $29.8 \mathrm{ppm}$. The coupling exhibited in the COSY spectrum between hydrogen at 1.60 (d) to the olefinic protons at $\delta 5.35$ confirmed the presence of terminal methyl adjacent to the double bond. The $\delta 2.36$ and cross peak $\delta 1.56$, showed connectivity between methylene and $\beta-\mathrm{CH}_{2}$ - group in the molecule. The base peak at $\mathrm{m} / \mathrm{z} 81$ was due to $\beta$-cleavage to the double bond and abundant peak at $m / z 235$ was due to $\alpha$-cleavage to ester group. The other abundant peaks at $m / z$ 179, 136, 109, 95, 67, 65, 55 and 41 were in agreement with the proposed structure. The fragmentation pattern was given in fluxogram (Figure 2).

The alkaline hydrolysis of dienoate (1), yielded a mixture of alcohol and carboxylic acid identified as methanol and dienoic acid. The unsaturated acid was brominated to yield 15, 16, 17, 18-tetrabromo derivative. ${ }^{20,21}$ The formation of tetrabromo derivative was revealed by the appearance of a pentet in mass spectrum, thus confirming two double bonds in the molecule.22

Thus on the basis of above evidences the dienoate (1) was characterized as methylnonadeca-15, 17-dienoate, it is a novel compound and being reported first time by us.

The mass spectral analysis of monoester (2) gave the molecular formula as $\mathrm{C}_{21} \mathrm{H}_{40} \mathrm{O}_{2}$.

IR Spectrum showed absorption bands for ester group $\left(1740 \mathrm{~cm}^{-1}\right)$, unsaturation $\left(1627 \mathrm{~cm}^{-1}\right)$ and long chain aliphatic nature $\left(730-720 \mathrm{~cm}^{-1}\right){ }^{1} \mathrm{H}$ NMR Spectrum showed a peak at $\delta 0.90$ as triplet for six protons was due to the terminal methyl groups. ${ }^{19}$ Methylene protons of $-\mathrm{CH}_{2}-$ $\mathrm{O}-\mathrm{CO}$ - and $-\mathrm{CH}_{2}-\mathrm{CO}-\mathrm{O}-$ moieties were resonated as two

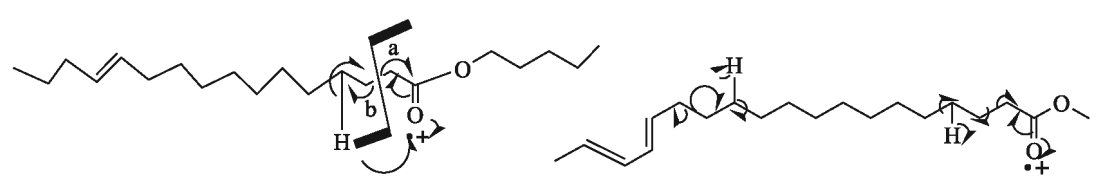

2

Modes of fragments $\quad 1$

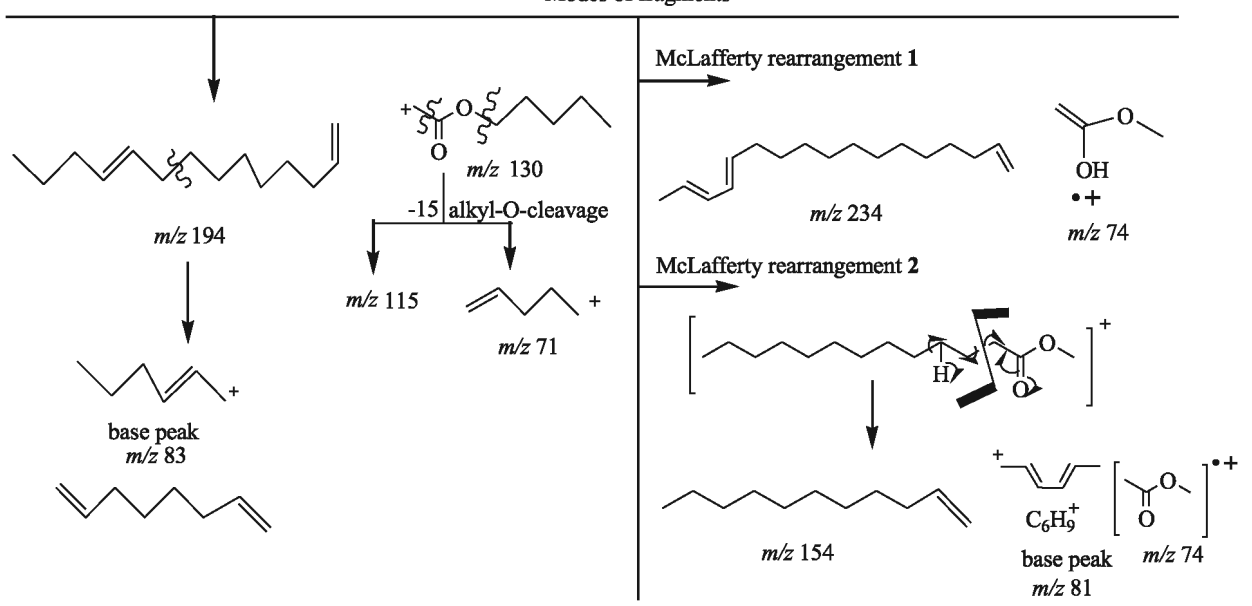

Figure 2. Fluxogram showing the fragmentation patterns proposed for dienoate $\mathbf{1}$ and monoester 2. 
triplets at $\delta 4.14$ and 2.36 respectively. A triplet at $\delta 5.35$ was due to unsaturated protons. A multiplet at $\delta 1.56$ was due to the presence of methylene protons $\beta$ - to the ester group and double bond, while rests of the methylenes were resonated at $\delta 1.25$ as an intense singlet.

The ${ }^{13} \mathrm{C}$ NMR spectrum of monoester (2) showed the presence of terminal methyl carbon at $19.9 \mathrm{ppm}$. The carbon of ester group was resonated at $174.0 \mathrm{ppm}$. The olefinic carbons at C-12 resonated at $118.0 \mathrm{ppm}$. The methylene carbons, $\alpha$ - and $\beta$ - to ester group were resonated at 34.5 and $32.0 \mathrm{ppm}$ respectively and rests of the methylene carbons were resonated at $29.8 \mathrm{ppm}$.

In mass spectrum the base peak at $m / z, 83$ was obtained due to $\beta$-cleavage to unsaturation and the abundant peak at $m / z, 115$ was due to cleavage to ester group, suggested the position of double bond and ester group. The other abundant peaks obtained at $\mathrm{m} / \mathrm{z}, 253,227,195,166,145$, 55 and 41 were inconsistent with the proposed structure. The fluxogram (Figure 2) showed the fragmentation pattern of monoester (2).

On alkaline hydrolysis of (2), a mixture of alcohol and carboxylic acid was obtained and identified as pentanol and acid. The unsaturated acid was brominated and identified as 12,13-dibromo hexadecanoic acid. ${ }^{20,21}$ The formation of dibromo derivative was confirmed by the appearance of a triplet in mass spectrum. ${ }^{22}$

Thus on the basis of above evidences the monoester 2 was characterized as a pentyl hexa deca-12-enoate.

It is a novel compound and reported first time by us. The molecular formula of naturally isolated monoester $(\mathbf{3})$ was $\mathrm{C}_{20} \mathrm{H}_{38} \mathrm{O}_{2}$. IR absorption bands $\left(1740,1627,720 \mathrm{~cm}^{-1}\right)$ and peaks in NMR spectrum and fragmentation modes of mass spectra indicated that chemical structure of $(\mathbf{3})$ was similar to (2), i.e., long chain aliphatic ester. The position of ester group was determined by mass fragmentation pattern $(\mathrm{m} / \mathrm{z}$, 241, 195, 166, 115, 83 (base peak), 55 and 41 .

Alkaline hydrolysis of monoester $(\mathbf{3})$, yielded a mixture of alcohol and carboxylic acid, identified as pentanol and pentadeca-11-en-oic acid respectively.

Thus on the basis of above evidences the compound (3) was characterized as a pentyl pentadeca-11-enoate.

The known natural compounds linoleic acid, oleic acid, $\beta$-sitosterol and stigmasterol were identified as part of the lipid structures by analysis of IR, ${ }^{1} \mathrm{H}$ NMR and ${ }^{13} \mathrm{C}$ NMR (DEPT) and mass spectral analysis and comparison with ${ }^{1} \mathrm{H}$ NMR and ${ }^{13} \mathrm{C}$ NMR data of literature (see experimental).

\section{Screening of antimicrobial activity}

Agar diffusion technique was used for the screening of antimicrobial activity, using paper disc method as reported in the literature. ${ }^{23,24}$ The results are shown in Table1. The results have shown that all compounds exhibited moderate activity against Staphylococcus aureus and poor activity against shigella spp. and K. pneumoniae.

Table 1. Antimicrobial assays for the 1-3

\begin{tabular}{|c|c|c|c|}
\hline $\begin{array}{c}\text { Antibacterial } \\
\text { activity / } \\
\text { Antifungal activity }\end{array}$ & 1 & 2 & 3 \\
\hline $\begin{array}{c}\text { Staphylococcus } \\
\text { aureus }\end{array}$ & + & ++ & ++ \\
\hline Proteus vulgaris & - & - & - \\
\hline Escherichia coli & - & - & - \\
\hline Shigella spp. & + & + & - \\
\hline Citobacter fruendi & - & - & - \\
\hline $\begin{array}{c}\text { Klebsiella } \\
\text { pneumoniae }\end{array}$ & + & - & - \\
\hline $\begin{array}{l}\text { Salmonella } \\
\text { typhimurium }\end{array}$ & - & 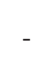 & - \\
\hline Aspergillus niger & - & + & - \\
\hline $\begin{array}{l}\text { Penicillium } \\
\text { notatum }\end{array}$ & + & - & - \\
\hline $\begin{array}{c}\text { Alternaria } \\
\text { alternate }\end{array}$ & - & + & - \\
\hline Candida albicans & - & - & + \\
\hline $\begin{array}{c}\text { Cunninghamella } \\
\text { spp. }\end{array}$ & - & + & + \\
\hline Aspergillus flavus & - & - & - \\
\hline
\end{tabular}

Disc diameter $=4.0 \mathrm{~mm} ;=$ No activity $+=6.8-8.0 \mathrm{~mm} ;++=9.0$ $11 \mathrm{~mm} ;+++=12-14 \mathrm{~mm} ;++++=; 16-20 \mathrm{~mm} ;+++++=18-14 \mathrm{~mm}$; For antibacterial activity. The standards are in the form of sterile Hi-Disc cartridges, each disc containing $10 \mathrm{mcg}$ of the respective drug. For antifungal activity Amphotericin B was used as standard.

\section{Experimental}

\section{General experimental procedures}

Melting points (mp) are uncorrected. ${ }^{1} \mathrm{H}$ NMR was recorded on $300 \mathrm{MHz}$ Varian XL spectrometer and $400 \mathrm{MHz}$ Brucker WM spectrometer, ${ }^{13} \mathrm{C}$ NMR spectra were recorded on Varian XL $75 \mathrm{MHz}$ spectrometer. ${ }^{1} \mathrm{H}-{ }^{1} \mathrm{H}$ COSY NMR was performed on the same spectrometer, using standard Varian pulse sequences. IR spectra were recorded in $\mathrm{KBr}$ discs on Perkin-Elmer-377 spectrometer, EIMS on JeolJMS D 300 mass spectrometer. Chromatography was performed using alumina grade III for column and silica gel $\mathrm{G}$ for TLC. The purity of the compounds were checked by ${ }^{1} \mathrm{H}$ and ${ }^{13} \mathrm{C}$ NMR spectral analysis and TLC plate, revealed with vanillin $(0.5 \mathrm{~g})$ in $\mathrm{H}_{2} \mathrm{SO}_{4}+\mathrm{EtOH}(4: 1)$. 


\section{Plant material}

The seeds of $N$. sativa Linn were collected from the nearby area of Ujjain city, identified from IEMPS, Vikram University, Ujjain.

\section{Extraction and isolation of the constituents}

The seeds $(6 \mathrm{~kg})$ of were shade dried, cleaned, coarse powdered and extracted with hexane in soxhlet extractor for $72 \mathrm{~h}$. The extract was concentrated by rotary evaporator to afford $(3500 \mathrm{~mL})$ oil. The oil was saponified by alcoholic potash method. ${ }^{25}$ Usual work up yielded (116 g) unsaponifiable matter which was separated by repeated column chromatography on alumina grade III. The column was eluted by gradient elution in increasing order of polarity. The fractions were collected in bulk and monitored by TLC. The residue $(6.8 \mathrm{~g})$ of hexane fraction was subjected to rechromatographed on alumina on basis of increasing order of polarity of eluents. Fractions 5-6 (hexane:benzene, v/v, $8: 2$ and 7:3) were purified and identified as linoleic acid and oleic acid respectively. Presence of these acids were analyzed by IR, ${ }^{1} \mathrm{H}$ NMR and mass spectrometry, and compared with literature data. ${ }^{26-29}$ Fractions 7-12 afforded a mixture of dienoate $\mathbf{1}$ and monoester $\mathbf{2}$ and other impurities. It was further rechromatographed, eluent hexane:benzene (4:1 and $3: 1, v / v)$ was eluted (1) and (2) in pure form, respectively. Fraction 13 yielded monoester $\mathbf{3}$ which was in crystal form. Rest of the fractions (hexane:benzene, v/v, $1: 1)$ yielded $\beta$-sitosterol and stigmasterol. The sterols were identified by comparison with literature data. ${ }^{30-32}$

\section{Methyl nonadeca-15, 17-dienoate (1)}

$\mathrm{M}^{+} 308, \mathrm{C}_{20} \mathrm{H}_{36} \mathrm{O}_{2}$ (40 mg, methanol), mp 90-92 ${ }^{\circ} \mathrm{C}$ (Found: C, 77.9; H, 11.68; Calc.: C, 77.7; H, 11.65\%), isolated from hexane: benzene $(4: 1, \mathrm{v} / \mathrm{v})$ fraction. On TLC examination it showed single spot using hexane: ether: acetic acid $(9: 1: 1, \mathrm{v} / \mathrm{v})$ as solvent system. IR $(\mathrm{KBr}) \lambda_{\max } / \mathrm{cm}^{-1}$ : 2958, 2919, 2854, 1730, 1651, 1627, 1460, 1170, 1020, $730-720 \mathrm{~cm}^{-1} .{ }^{1} \mathrm{H}$ NMR (200 MHz, $\left.\mathrm{CDCl}_{3}, \mathrm{TMS}, \delta\right) 1.60$ $\left(3 \mathrm{H}, \mathrm{d},-\mathrm{CH}_{3}, J 7.5 \mathrm{~Hz}\right), 3.64\left(3 \mathrm{H}, \mathrm{s},-\mathrm{CH}_{3}\right), 2.36(2 \mathrm{H}, \mathrm{t}$, $\left.-\mathrm{CH}_{2}-\mathrm{CO}-\mathrm{O}-, \mathrm{J} 6.0 \mathrm{~Hz}\right), 1.56\left(4 \mathrm{H}, \mathrm{m}, 2 \mathrm{x}-\mathrm{CH}_{2}, \beta\right.$ to double bond and ester group), $5.35(4 \mathrm{H}, \mathrm{m}, 2 \mathrm{x}-\mathrm{CH}=\mathrm{CH}-), 1.25$ $\left(18 \mathrm{H}, \mathrm{s}, 9 \mathrm{x}-\mathrm{CH}_{2}\right)$. EIMS m/z (rel. int.,\%) $308\left[\mathrm{M}^{+}\right]$(1.1), 279 (5.1), 263 (1.2), 250 (1.3), 236 (3.5), 207 (7.2), 180 (7.7), 164 (17.9), 147 (18.8), 136 (26.1), 123 (26.5), 121 (31.1), 109 (28.6), 95 (62.6), 81 (100), 67 (92.0), 55 (95.8), 41 (78.2), 29 (38.1). ${ }^{13} \mathrm{C} \mathrm{NMR} \mathrm{(75} \mathrm{MHz,} \mathrm{CDCl}_{3}, \mathrm{TMS}, \delta$ ) 174.0,118.0, $122.0,34.5,32.0,29.8,19.9$.

Dienoate $1(2.0 \mathrm{mg})$ was refluxed with ethanolic $\mathrm{KOH}(1.3 \mathrm{~mL}, 5 \%)$ for $1 \mathrm{~h}$. At the end of the reaction, the mixture was diluted with water $(3.0 \mathrm{~mL})$ and extracted with chloroform. The chloroform layer was dried over anhydrous magnesium sulphate and concentrated. To separate both the compounds it was put in deep freezer. After 4 days some semi solid mass was separate out. After usual work-up, the solid was identified as an acid (IR: $3420,1720 \mathrm{~cm}^{-1}$ ) and liquid gave positive test for alcohol.

$(1.0 \mathrm{mg})$ of an acid in diethyl ether $(10 \%)$ was treated with drop wise addition of $2-3 \mathrm{~mL}$ of bromine in cold condition $\left(-10^{\circ} \mathrm{C}\right)$ from a finely drawn pipette, with constant stirring the reaction mixture..$^{20,21}$ Addition of bromine was continued until a persistent reddish-yellow color was obtained. After standing 25 minutes, excess of bromine was destroyed by adding $\beta$-amylene and then it was kept in cold condition till over night. After usual work up, the solid was crystallized by adding cold petro naptha in ethereal solution and identified as 15, 16, 17, 18-tetrabromo nonadecanoic acid.

\section{Pentyl hexadec-12-enoate (2)}

$\mathrm{M}^{+} 324, \mathrm{C}_{21} \mathrm{H}_{40} \mathrm{O}_{2}\left(35 \mathrm{mg}\right.$, methanol), mp 101-102 ${ }^{\circ} \mathrm{C}$ (Found: C, 77.7; H, 12.3; Calc.: C, 77.5; H, 12.1\%), isolated from hexane: benzene $(3: 1, \mathrm{v} / \mathrm{v})$ fraction. On TLC examination it showed a single homogenous spot using hexane: ether: acetic acid (9.5:0.5:0.5, v/v). IR (KBr) $\lambda_{\max } / \mathrm{cm}^{-1}: 2920,2860,1740,1627,1470,1390$, and 730-720 cm-1. ${ }^{1} \mathrm{H}$ NMR (200 MHz, $\mathrm{CDCl}_{3}, \mathrm{TMS}, \delta$ ) 0.90 $\left(6 \mathrm{H}, \mathrm{t}, 2 \mathrm{x}-\mathrm{CH}_{3}, J 7.5 \mathrm{~Hz}\right), 4.14\left(2 \mathrm{H}, \mathrm{t},-\mathrm{CH}_{2}-\mathrm{O}-\mathrm{CO}-, J 6.0\right.$ $\mathrm{Hz}), 2.36$ (2H, t, -CH $-\mathrm{CO}-\mathrm{O}-, J 6.0 \mathrm{~Hz}), 1.56(8 \mathrm{H}, \mathrm{m}$, $4 \mathrm{x}-\mathrm{CH}_{2}, \beta$ to double bond and ester group), $5.35(2 \mathrm{H}, \mathrm{t}$, $-\mathrm{CH}=\mathrm{CH}-, J 7.0 \mathrm{~Hz}), 1.25\left(20 \mathrm{H}, \mathrm{s}, 10 \mathrm{x}-\mathrm{CH}_{2}\right)$. EIMS $\mathrm{m} / \mathrm{z}$ (rel.int., \%) $324\left[\mathrm{M}^{+}\right]$(1.1), 279 (2.2), 253 (3.1), 239 (1.5), 227 (44.8), 195 (52.4), 177 (3.0), 166 (30.0), 145 (38.6), 115 (91.2), 95 (33.1), 83 (100), 71(26.7), 67 (29.5), 55 (77.7), 41 (38.1). ${ }^{13} \mathrm{C} \mathrm{NMR} \mathrm{(75} \mathrm{MHz,} \mathrm{CDCl}_{3}, \mathrm{TMS}, \delta$ ) 174.0, 118.0, 34.5, 32.0, 29.8, 19.9.

Monoester 2(2.0 mg) was refluxed with ethanolic $\mathrm{KOH}(1.3 \mathrm{~mL}, 5 \%)$ for $1 \mathrm{~h}$. At the end of the reaction, the mixture was diluted with water $(3.0 \mathrm{~mL})$ and extracted with chloroform. The chloroform layer was dried over anhydrous magnesium sulphate and concentrated. To separate both the compounds it was put in deep freezer. After 4 days some semi solid mass was separate out. After usual work-up, they were identified as an acid (IR: $3420,1720 \mathrm{~cm}^{-1}$ ) and liquid gave positive test for alcohol.

\section{Pentyl pentadec-11-enoate (3)}

$\mathrm{M}^{+} 310, \mathrm{C}_{20} \mathrm{H}_{38} \mathrm{O}_{2}\left(40 \mathrm{mg}\right.$, methanol) $\mathrm{mp} 82-83{ }^{\circ} \mathrm{C}$ (Found C, 77.4; H, 12.2; Calc C, 77.1; H, $12.0 \%$ ), isolated from hexane: benzene $(1: 1, \mathrm{v} / \mathrm{v})$ fraction TLC hexane: ether: acetic acid (9:1:1, v/v) as solvent system, it showed single 
clear spot. IR (KBr) $\lambda_{\max } / \mathrm{cm}^{-1}: 2920,2860,1740,1627$, 1470, 1390, and 730-720 cm ${ }^{-1} .{ }^{1} \mathrm{H}$ NMR $\left(200 \mathrm{MHz} \mathrm{CDCl}_{3}\right.$ , TMS, $\delta) 0.90\left(6 \mathrm{H}, \mathrm{t}, 2 \mathrm{x}-\mathrm{CH}_{3}, J 7.5 \mathrm{~Hz}\right), 4.14\left(2 \mathrm{H}, \mathrm{t},-\mathrm{CH}_{2}-\right.$ O-CO-, J 6.0 Hz), 2.36 (2H, t, - $\mathrm{CH}_{2}-\mathrm{CO}-\mathrm{O}-$, J $6.0 \mathrm{~Hz}$ ), 1.56 $\left(8 \mathrm{H}, \mathrm{m}, 4 \mathrm{x}-\mathrm{CH}_{2}, \beta\right.$ to double bond and ester group), 5.35 $(2 \mathrm{H}, \mathrm{t},-\mathrm{CH}=\mathrm{CH}-, J 7.0 \mathrm{~Hz}), 1.25\left(20 \mathrm{H}, \mathrm{s}, 10 \mathrm{x}-\mathrm{CH}_{2}\right)$. EIMS $\mathrm{m} / \mathrm{z}$ (rel.int., \%) $310\left[\mathrm{M}^{+}\right]$(1.1), 279 (5.2), 242 (2.1), 241 (47.3), 212 (6.3), 195 (51.0), 166 (27.8), 145 (30.0), 124 (17.5), 115 (99.7), 95 (38.2), 83 (100), 69 (31.1), 67 (31.2), 55 (81.5), 41 (39.8). ${ }^{13} \mathrm{C}$ NMR (75 MHz, $\mathrm{CDCl}_{3}, \mathrm{TMS}, \delta$ ) 174.0, 118.0, 34.8, 32.5, 29.8, 19.9.

Monoester $3(2.0 \mathrm{mg})$ was refluxed with ethanolic $\mathrm{KOH}(1.3 \mathrm{~mL}, 5 \%)$ for $1 \mathrm{~h}$. At the end of the reaction, the mixture was diluted with water $(3.0 \mathrm{~mL})$ and extracted with chloroform. The chloroform layer was dried over anhydrous magnesium sulphate and concentrated. To separate both the compounds it was put in deep freezer. After 4 days some semi solid mass was separate out. After usual work-up, it was identified as an acid (IR: 3420, $1720 \mathrm{~cm}^{-1}$ ) and liquid gave positive test for alcohol.

\section{Screening of antimicrobial activity}

Agar diffusion technique was used for the screening of antibacterial and antifungal activities using paper disk method. ${ }^{23,24}$ The results are being shown in Table 1 .

\section{Acknowledgments}

Authors are grateful to RSIC, CDRI, Lucknow and RSIC; IIT Bombay, Mumbai for spectral analysis and UGC, New Delhi for financial assistance.

\section{References}

1. Satavati, G. V.; Gupta, A. K.; Medicinal Plants of India, Dehradun, 1987, vol.1.

2. Anon; Wealth of India, CSIR: New Delhi, 1991, vol. 3, pp. 63-65.

3. Atta-Ur-Rahaman; Malik, S.; Hasan, S. S.; Chaudhary, M. I.; Nie, N.; Clardy, J.; Tetrahedron Lett. 1995, 1993.

4. Atta-Ur- Rahaman; Malik, S.; Zaman, K.; J. Nat. Prod. 1992, 55, 676.

5. Atta-Ur-Rahaman; Malik, S.; Cun-heng-H.; Clardy, J.; Tetrahedron Lett. 1985, 2759.

6. Salma, R. B.; Planta Med. 1973, 24, 375.

7. Ansar, A. B.; Hassan, S.; Kanne, L.; Atta-Ur-Rahaman; Wohler, T.; Phytochemistry 1988, 27, 3977.
8. Chakravarti, N.; Annu. Allergy 1993, 70, 237.

9. Al-Naggar, T. B.; Gomez-Serranillos, M. P.; Carreto, M. E.; Villar, A. M.; J. Ethnopharmacol. 2003, 88, 63.

10. Sharma, P. V.; Dravyaguana-Vijnana, Chaukhambha Bharti Academi:Varanasi, 1998, vol. 2, pp. 596, 597.

11. Hailat, N.; Bataineh Z.; Lafi, S.; Rowdily, E.; Aquel, M.; Muhamad, Al-Katib; Hanash, S.; Int. J. Pharmacog. 1995, 33, 16.

12. Chopra, R. N.; Nayer, S. L.; Chopra, I. C.; Glossary of Indian Medicinal Plants, CSIR: NewDelhi, 1956, pp. 176,177.

13. El-Alfy, T. S.; El-Fatatry, H. M.; Toama, M. A.; Pharmazie 1975, 30, 109.

14. Ali, B. H.; Blunden, G.; Phytother. Res. 2003, 17, 299.

15. Boulos, L.; Reference Publication 1983,103.

16. Mehta, B. K.; Singh, N.; Keshri, G.; Chaudhary, S. R.; Biol. Memories 1999, 25, 38.

17. Dyer, J. R. Application of Absorption Spectroscopy of Organic Compound, Prentice Hall of India Ltd.: New Delhi, 1984, p.35.

18. Bellamy, L. J.; The Infrared Spectra of Complex Molecules, Chapman and Hall: London, 1975, p. 39.

19. Silverstein, R. M.; Webster, F. X.; Spectrometric Identification of Organic Compounds $6^{\text {th }}$ ed., John Wiley and Sons: New York, 2003, pp.160-253.

20. Birosel, D. M.; Univ. Philippines Nat. Appl. Sci. Bull. 1932, 2,103 .

21. Kass, J. P.; Burr, G. O.; J. Am. Chem. Soc. 1939, 61, 1062.

22. Mohan, J.; Organic Spectroscopy Principles and Applications, Narosa Publishing House: New Delhi, 2000, p.366.

23. Maruzzella, I. C.; Henry, P. A.; J. Am. Pharm. Assoc. 1958, 47, 294.

24. Vincent, J. G.; Vincent, H. W.; Proc. Soc. Expt. Biol. Med. 1995, 55,712 .

25. Mohan, J.; Organic Analytical Chemistry, Narosa Publishing House: New Delhi, 2003, p. 533.

26. Huber, W. F.; J. Am. Chem. Soc. 1951, 73, 2732.

27. Swern, D.; Coleman, J. E.; J. Am. Oil Chem. Soc. 1955, 32, 539.

28. Bernhard, K.; Helv. Chim. Acta 1948, 31, 977.

29. Crombie, L.; J. Chem. Soc. 1962, 2449.

30. Francis, G. W.; Veland, K.; J. Chromatogr. 1981, 219, 379.

31. Pouchert, C. J.; Behnke, J.; The Aldrich Library of ${ }^{13} \mathrm{C}$ and ${ }^{1} \mathrm{H}$ NMR Spectra, $1^{\text {st }}$ ed., 1993, vol.1, 2.

32. Maitra, S. K.; Chatterjee, B. N.; Chakravarti, D.; Maiti, B. C.; J. Indian Chem. Soc. 2006, 83, 513.

Received: May 31, 2007

Web Release Date: February 27, 2008 